\title{
THE 1996 WORLD MICROCOMPUTER CHESS CHAMPIONSHIP
}

\author{
Jakarta, Indonesia \\ October $7^{\text {th }}-16^{\text {th }}, 1996$ \\ David Levy ${ }^{1}$
}

The ICCA has received 26 entries for the 1996 World Microcomputer Chess Championship, which will be held in Jakarta, Indonesia, from October 7 to October 16, 1996. There are 24 amateur entries and 2 professional entries. All entries have been accepted for particıpation. We list them below.

\section{Amateur programs}

\begin{tabular}{|c|c|c|}
\hline Program & Programmer(s) & Country \\
\hline BREAKTHROUGH II & Werner Koch & Germany \\
\hline CENTAUR & Victor Vikhrev, Alexeı Manjakhın & Russia \\
\hline COMET & Ulrich Turke & Germany \\
\hline CRAFTY & Bob Hyatt, Mike Byrne, Bett Gower & USA \\
\hline DARK THOUGHT & $\begin{array}{l}\text { Peter Gillgasch, Markus Gille, Ernst Heinze } \\
\text { [Gillgasch is no longer a member of this team.] }\end{array}$ & Geımany \\
\hline DIOGENES 2.0 & Jorg Burwitz, Karsten Bauermeister & Germany \\
\hline EUGEN-7 & Eugenı Jimenez & Span \\
\hline FERRET & Bruce Moreland & USA \\
\hline FRANCESCA & Tom King & England \\
\hline GANDALF $\mathrm{X}$ & Steen Surballe, Dan Wulff & Denmark \\
\hline HEUREKA & Gerold Fischer & Geimany \\
\hline ISICHESS 2.5 & Gerd Isenberg & Geımany \\
\hline NIGHTMARE & Reınhold Gellner and Gaby von Rekowskı & Geımany \\
\hline NimZO-3 & Chrilly Donnınger, A. Kurp & Austria \\
\hline PATZER & Roland Pfister & Geımany \\
\hline SCHACH 3 & Matthras Engelbach & Germany \\
\hline SHREDDER & Stefan Meyer-Kahlen & Germany \\
\hline THETURK & Yngvi Bjornsson, Andreas Junghanns & Canada \\
\hline $\mathrm{XXXX} 2.0$ & Martın Zentner & Germany \\
\hline ZEUS 3.1 & Gerardo Castano & Span \\
\hline INTERCHESS & Michael Borgstadt, Spomenka Grabusıc & Germany \\
\hline ANANSE & Walter Bannerman & Switzerland \\
\hline WOODPUSHER & John Hamlen & England \\
\hline GULLYDECKEL & Martın Borriss & Geımany \\
\hline
\end{tabular}

1 89, Constantıne Road, London, NW3 2LP England. Ema11 DavidL@ıntrsrch.demon.co.uk. 


\section{Professional programs}

\begin{tabular}{|l|l|l|}
\hline Program & Programmer(s) & Country \\
\hline FRITZ & $\begin{array}{l}\text { Frans Morsch } \\
\text { Mathias Feist, Matthias Wullenweber }\end{array}$ & $\begin{array}{l}\text { The Netherlands } \\
\text { Germany }\end{array}$ \\
\hline VIRTUAL CHESS 2 & Marc-Francois Baudot, Jean-Christophe Weill & France \\
\hline
\end{tabular}

\section{Tournament Officials}

The Tournament Director will be Jaap van den Herik. Tony Marsland will also be present for most (hopefully all) of the tournament and will be able to assist anyone with problems, particularly during the set-up and early stages of the event. The local organizer is Mr. Bunawan, Gunadarma University, (Gedung 2, lantai 2), Jl. Margonda Raya 100, Pondok Cina, Depok 16424, Indonesia. Email: gdarma2@rad.net.id.

\section{Hotel}

Since traffic in Jakarta is really heavy the local organisers have selected a hotel which is not too far from the playing hall. The playing venue will be in a brand new, 8-storey, fully-airconditioned building, located in the heart of the business district beside the old Dutch-style building of The University of Indonesia with its General Hospital.

Participants and officials will be staying in the 4-star Dai-Ichi Hotel, which is owned and operated by a Japanese group and is part of a worldwide hotel chain. The hotel's facilities include a 24-hour coffee shop, Japanese restaurant, Royal Class Chinese restaurant, Le Parisienne restaurant, Massage Parlour, Department Store, Traditional Handicraft Plaza, Golden Ballroom (which will be used for the Opening and Closing Ceremonies), with 9 floors and 300 rooms. There is a 3-level underground parking lot for anyone who wishes to rent a car.

This hotel is considered by our hosts to be of the same standard as a 5-star hotel, but because it has no tennis court it does not have a 5-star rating. We have been advised however that if you enjoy tennis or golf you should bring your own racket or clubs; the local organisers will be happy to accompany you for a game!

The normal rate for this hotel is US $\$ 180$ per night (room only) whether for single or double. Tournament participants will be charged only US $\$ 40$ nett per night for a room (without breakfast), and the balance will be paid by our sponsors.

\section{Dining and Transportation Arrangements}

Please remember that the hotel room rate does NOT include breakfast, which costs US \$13 per person.

Lunch during the tournament will be provided at the playing hall by our hosts, Gunadarma University. Dinner in the hotel costs US \$16. (Lunch in the hotel is US \$15.)

Transportation between the hotel and the tournament venue will be arranged by Gunadarma University.

Transportation between Jakarta airport and the hotel will be arranged by Gunadarma University. Those of you making your own travel arrangements should let Mr. Bunawan know your flight number and arrival time/date so that you can be met on arrival.

\section{Playing Venue}

J1. Kenari III/5, Jakarta Pusat, Indonesia. Tel: +62-21-330220 or +62-21-330226 Fax: +62-21-7863788.

\section{Computers}

Our hosts are providing on loan a $133 \mathrm{MHz}$ P5 computer with $16 \mathrm{MB}$ RAM and $540 \mathrm{MB}$ hard disk for anyone who needs one. All requests for computer hardware have been passed on to Mr. Bunawan.

Anyone requiring a different computer must plan to make their own arrangements, though we are asking 
Mr. Bunawan to help. An update will be provided on computer availability around September 15 th.

If you are taking your own computer to Jakarta please send Mr. Bunawan full details (make, model, serial number) so that he can arrange for customs formalities to be minimized on arrival.

\section{Titles}

Just to remind everyone the following titles will be awarded. (For the other rules please see our original anouncement published in the June issue of the ICCA Journal, pp. 136-141.)

\section{The following titles will be awarded at the tournament:}

[a] 1996 Absolute World Microcomputer Chess Champion - for the overall winner of the tournament.

[b] 1996 World Microcomputer Amateur Chess Champion - for the highest-placed entry by a team made up entirely from amateur programmers.

[c] 1996 Dedicated Chess Computer World Champion - for the highest-placed entry by a dedicated chess computer.

The order of finish will be determined by the total number of points earned. In the event of a tie for any of the titles a one-game play-off will be organized between the tied programs. If more than 2 programs are involved in the tie the play-off game will be between the two programs which have the best tie-break scores (see below). The rate of play for a play-off game will be decided by the Tournament Director, bearing in mind the time available to play the game. If the play-off game is drawn then the tie-breaking method will be used to determine the winner of the title. The first tie-break will be by the sum of the opponents' scores. If there is still a tie it will be broken on the basis of the sum of the respective programs' cumulative scores after each round (i.e., score after round $1+$ score after round $2+\ldots . .+$ score after round 11 ).

\section{CALENDAR OF COMPUTER-GAMES EVENTS 1996}

\section{October 7-16, 1996}

The 1996 World Microcomputer Chess Championship to be held in Jakarta, Indonesia.

For details see pp. 206-208 in this issue.

November 9-10 and 16-17, 1996

The Open 1996 Dutch Computer-Chess Championship, to be held at the CRI, University of Leiden, The Netherlands.

Details from Theo van der Storm, Weth. Driessenstraat 5, 1107 XG Amsterdam Zuidoost, The Netherlands. Email: tst@dasc.nl.

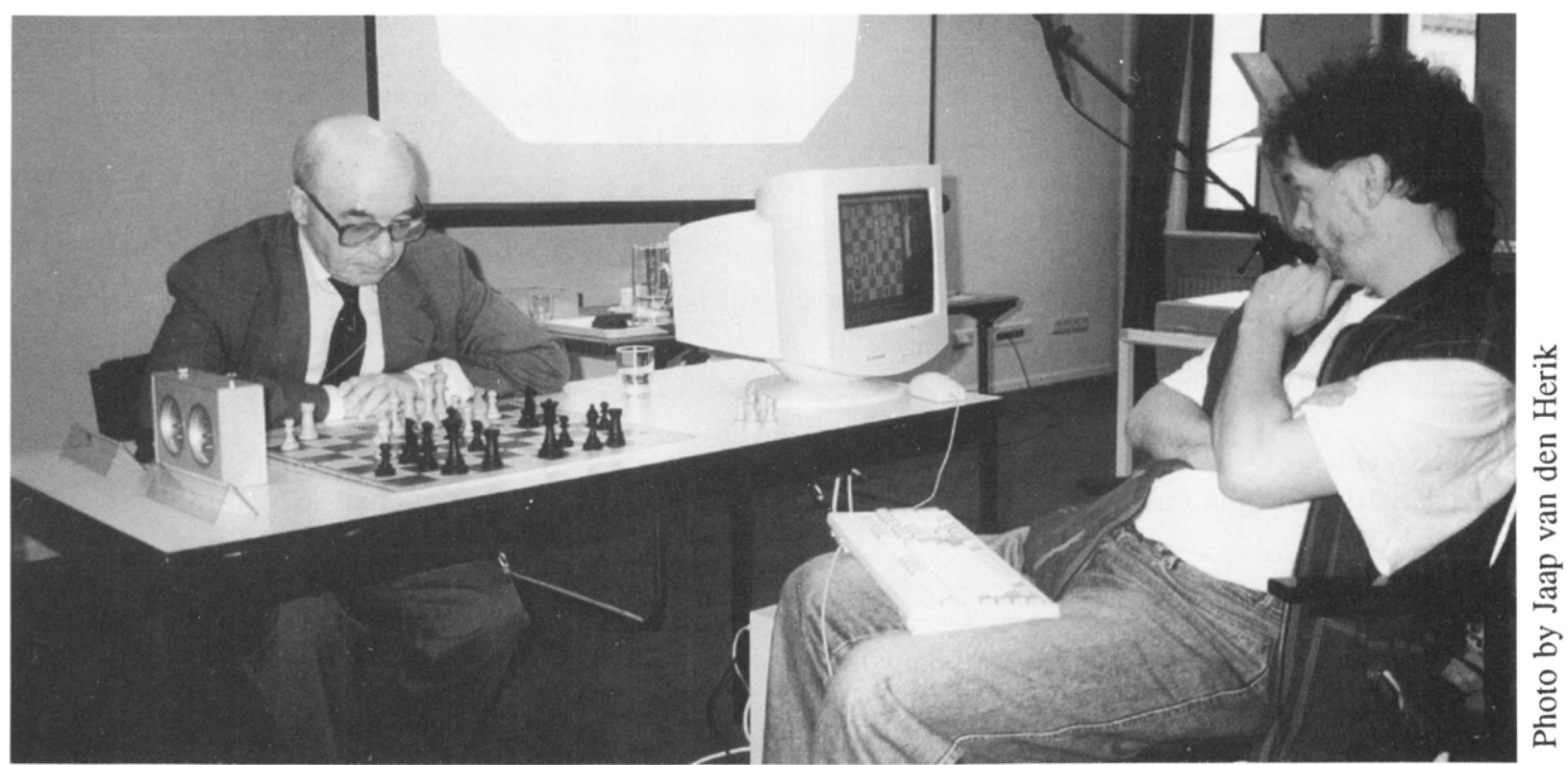

CHESS CHALLENGER DAVID BRONSTEIN ON HIS WAY TO VICTORY

Bronstein, Guest of Honour, defeating M_CHESS PRO, operated by Gerd Isenberg.

Vaeshartelt, Maastricht, June 27, 1996. 